\title{
Silicified Mississippian brachiopods from Muhua, southern China: Lingulids, craniids, strophomenids, productids, orthotetids, and orthids
}

Yuanlin Sun and Andrzej Baliński

Acta Palaeontologica Polonica 53 (3), 2008: 485-524 doi:http://dx.doi.org/10.4202/app.2008.0309

This paper describes 37 species (4 new) belonging to 27 genera (1 new), 14 families, and 6 orders (Lingulida, Craniida, Strophomenida, Productida, Orthotetida, and Orthida) of silicified brachiopods from the middle Tournaisian (Mississippian, lower Carboniferous) of the vicinity of Gedongguan and Muhua villages (southern China). All specimens come from acid etching of detrital and oolitic limestone lenses scattered within grey to black laminated basinal micrite and marl of the Muhua Formation. The formation, which attains about 1-10 meters in thickness, is dated to the Siphonodella crenulata Zone. More than 10,000 silicified brachiopod specimens belonging to about 70 species were recovered from over $900 \mathrm{~kg}$ of the sampled limestone lenses, the most diverse brachiopod fauna of that age. The characteristic feature of the studied material is the prevailing disarticulation and fragmentation of skeletal parts due to their down slope transportation into a deeper water environment. Within Lingulida, one linguloid and one discinoid species are described. Craniida are represented by five species including Nematocrania pilea sp. nov.

Strophomenida are represented by fragmentarily preserved specimens belonging to one species. The most diverse are Productida, which are represented by 7 chonetidine and 12 productidine species; new are Subglobosochonetes gedongguanensis sp. nov. and Globosochonetes gracilis sp. nov. New data on morphology of larval stage of Argentiproductus margaritaceus and its mode of attachment are presented. Orthotetida is represented by 5 species including Lamellispina spinosa gen. et sp. nov. Orthida is represented by 3, mostly cosmopolitan species. This study of a middle Tournaisian brachiopod fauna from Muhua, together with published data on the Mississippian brachiopods from other regions of South China, allow to study the Devonian-Carboniferous biotic crisis and post-crisis recovery.

Key words: Brachiopoda, silicification, Carboniferous, Mississippian, Tournaisian, China

Yuanlin Sun [ylsun@pku.edu.cn], Department of Geology, Peking University, Beijing 100871, China; Andrzej Baliński [balinski@twarda.pan.pl], Instytut Paleobiologii PAN, ul. Twarda 51/55, PL-00-818Warszawa, Poland. 
This is an open-access article distributed under the terms of the Creative Commons

Attribution License (for details please see creativecommons.org), which permits unrestricted use, distribution, and reproduction in any medium, provided the original author and source are credited.

For Full text $(5,519.6 \mathrm{kB})$ 